The Version of Record of this manuscript has been published and is available in The Journal of North African Studies, published online 16 September 2019, http://www.tandfonline.com. DOI: 10.1080/13629387.2019.1665282

To cite this article: Francesco Vacchiano \& Hafsa Afailal (2019): 'Nothing will ever be the same again'. Personal commitment and political subjectivation in the 20 February Movement in Morocco, The Journal of North African Studies, DOI: $10.1080 / 13629387.2019 .1665282$

\title{
'Nothing will ever be the same again'. Personal commitment and political subjectivation in the 20 February Movement in Morocco
}

\author{
Francesco Vacchiano \& Hafsa Afailal \\ Instituto de Ciências Sociais, Universidade de Lisboa, Lisbon, Portugal
}

ABSTRACT

Based on an analysis of the stories of engagement of young activists who took part in the 20 February Movement in Morocco, this contribution explores the process of individual transformation that occurred during the experience of activism. We use the concept of political subjectivation to discuss the succession of moments of rupture and re-semanticisation, the new ethical configurations generated by the experience of activism and their long-term consequences. This contribution is part of an ethnographic study that has accompanied the evolution of the protests from 2011, carried out by the two authors first independently and, from 2017, within the framework of the 'Globally Sensitive: Revolt, Citizenship, and Expectations for the Future in North Africa' project.

KEYWORDS: Morocco; 20 February Movement; activism; political subjectivation

\author{
We need the formation of this insurrectional \\ collective subjectivity for which what was bearable \\ becomes unbearable [...] \\ How do these 'same' become others? What is this \\ transformative energy by which 'I', 'We' are no \\ longer as before?
}

Fethi Benslama, Soudain la Révolution!

\section{Introduction}

The popular uprisings of 2011, commonly known as the 'Arab Spring', have probably constituted the most substantial topic in scholarship dedicated to the Middle East and North Africa over the last years. The events preceding and following the self-immolation of Tāriq Muhammad Al-Bou 'Azizi have been scrutinised from a variety of perspectives and their ambiguous outcomes are still the subject of intense debate. Numerous analyses have pointed to the combination of state authoritarianism and cronyism as providing fertile ground for the revolts (Hibou 2006, 2011; Campante and Chor 2012; Bayart 2013; Bono et al. 2015). Authors have particularly emphasised how, in the last thirty years, the traditional strategies of power and resource accumulation have been reformulated within a new neo-liberal agenda, enlarging the gap between classes and furthering a sense of immobility and frustration in society (King 2007; Bogaert 2013; Almodóvar 2014; Hanieh 2013; Akçali 2016; Bogaert 2018). The condition of youth has been pivotal in these analyses, owing both to young people's representativeness in society and to their protracted 'waithood' in the delayed process of generational transition (Dhillon, Dyer, and Yousef 2009; Osman 2012; Murphy 2012; Honwana 2013; Muldering 2013; Shafer 2015; Belghazi and Moudden 2015). Several authors agree in identifying Middle Eastern youth as a historically specific 'sociological generation', marked by cultural experiences and ambitions that are relatively distinct from the past (Desrues 2012; Murphy 2012; Gertel 2017).

Against this backdrop, the combination of capitalistic pressures for accumulation and self-improvement, together with the reality of uneven opportunities at home has motivated young - and often very young - people of lower classes to pursue a possible future in a coveted and distant elsewhere (Vacchiano 2014, 2018a). This happened before, after and also during the days of the revolt (Tazzioli 2017). While such factors are commonly evoked to provide a context for the sudden outburst of protests that occurred in 2011, numerous authors have discussed the 
conditions that precipitated the events, some emphasising the unleashing effect of social media, and others the role of grass-roots organisations in laying the ground for revolt.

Each of these contributions sheds partial light on the events. Yet, they mostly explore the historical, political and social dynamics underlying popular discontent. Whereas structural factors are certainly relevant, they are not sufficient per se to explain people's disposition to take an active role in mobilisations. In point of fact, very few scholars have as yet tried to include subjects' choices and intimate motivations in their attempts to understand the 2011 revolts (see examples in Abdelrahman 2011 and Benslama 2011). In this contribution we try to retain a sense of the societal factors behind the 2011 uprisings while giving attention to the individuals involved, by exploring the ways in which people decided to step forward and make a personal commitment to political change. By foregrounding figures, we do not mean to disregard the background, but instead to study their interdependence and explore how circumstances influence choices and, in turn, how people concur in producing events. For, as compelling as a collective moment might be for those participating in it, such events are also made by and through personal stories.

The idea of exploring the 2011 uprisings from this angle came from our conversations with Moroccan activists, in which they generally agree that the results of the wave of demonstrations that occurred in 2011 lie well below expectations. Yet, they also recurrently remark that, despite their disappointment, 'nothing will ever be the same again'. Now, we could easily dismiss this statement as a case of 'cognitive dissonance' (the need to justify personal engagement in terms of rationality and success), a framework that would also explain why activists are usually more prone to give a positive assessment of the events (Festinger 1957). However, if we really want to grasp the subjective meaning of the experience, we are called upon to take this statement seriously and ask: what has allegedly changed forever? If the common, widespread perception of the events that unfolded after the selfsacrifice of Bou 'Azizi is one of disillusionment, what do protagonists think has been, nonetheless, permanently achieved?

By spotlighting individual decision, we aim to observe the ways in which one comes to undertake a politically informed process of reflection and choice. As we will see, this does not mean that people are necessarily fully aware of their reasons for (or the consequences of) their actions, but that, given a certain combination of historical dynamics and events, they can assume new forms of positioning as a result of a subjective shift. While there is a long tradition of studies concerning 'daily resistance' and 'tactics' (De Certeau 1990), 'infra-politics' and 'hidden transcripts' (Scott 1985, 1990) and 'non-movements' (Bayat 2010), it seems to us that much less has been written about the moments in which people stop resisting and start revolting (Thomassen 2012).

Young people are at the core of our analysis. However, youth is not only a matter of age, but a category characterised by a peculiar federative quality, one that allows people of different ages and walks of life to imagine, if not a common programme, at least a common condition. In our discussion, it is pertinent mainly as an 'emic' concept, owing to the fact that our interlocutors liked to use it to imagine themselves in relation to their world.

This contribution results from ethnographic work started in 2011 and carried out by the two authors in Morocco and Tunisia, first separately and, from 2017, under the common framework of the 'Globally Sensitive: Revolt, Citizenship, and Expectations for the Future in North Africa' research project, funded by the Portuguese Council for Scientific Research. ${ }^{1}$ We met and, whenever possible, interviewed young activists who participated in the 20 February Movement in Morocco, in order to explore with them their paths of engagement during and after 2011. Additionally, we recovered some of the interviews carried out by Hafsa Afailal for the realisation of the volume ' 20 February Movement. An Attempt of Documentation', published in Arabic by the Mediator for Democracy and Human Rights. ${ }^{2}$ Our goal was to explore the subjective transformations related to their experience of activism. We use the concept of 'political subjectivation' as a tool that allows us to think, as we will discuss in the next section, the succession of moments of rupture and re-semanticisation, the elaboration of new worldviews and new ethical configurations related to the experience of political engagement, as well as their long-term consequences.

\section{Political subjectivation, or a theory of freedom}

In our analysis, we propose to use the concept of 'political subjectivation' to describe the process of individual transformation related to the experiences in which a new ethical orientation, a new representation of oneself and the world and a new propensity for engagement and action emerge. In our understanding, the concept includes that of 'political socialization' insofar as it considers the importance of primary and secondary relations for the maturation of ethical and political values (Petrovic, van Stekelenburg, and Klandermans 2014). On the one hand, we wish to explore the ways in which our interlocutors came to the decision to act. On the other hand, we analyse the aftermaths of their choices and their consequences in the long run.

In a perspective that intersects psychoanalysis and poststructuralist anthropology, we consider subjectivation as the endless process in which we become particular individuals through our relationship with other people, objects 
and physical spaces that impose an embodied order of values and meanings. ${ }^{3}$ Such an order, incorporated mostly through sensations and affects and, therefore, largely unconscious, constitutes a relatively predictable set of orientations, according to which an individual complies with and reacts to the world. However, due to the multiplicity of forms of being and living in the world and the ontogenic nature of human experience, this largely unacknowledged set of values and meanings is neither coherent nor permanent, and - to a certain extent responds to circumstances and changes over time.

For us, subjectivation is therefore the process in which individuals, striving to define themselves in relation to the world and their experience of it, elaborate new affective and cognitive repertoires in order to orient their action amidst a series of possible alternatives. In our analysis, subjectivation is 'political' when personal change emerges in a process in which a specific vision of society and collective future is intentionally pursued.

The notion of political subjectivation has been largely employed in political philosophy, although not always consistently and, at times, without a clear theorisation of how exactly the subject should be conceptualized. This long genealogy, which goes from Arendt to Rancière via Foucault, Butler, Laclau, Deleuze, Žižek and others (recently examined by Tassin 2012 and Tarragoni 2016), focuses specifically on the process of transformation that is induced by experience and its potentialities for political change. Despite differences, these authors agree that subjectivation is an unfinished process of differentiation and, as such, an opening to a condition of uncertainty. For Hannah Arendt, the subject is not obliged by his past but must constantly invent it through a movement of singularisation that makes one 'other' and which is political in the first place (Arendt 1958).

This reflection finds an echo in Foucault's later works, in which subjectivation is described as a process that is concurrently a subjection to practices of sovereignty and a productive possibility of difference. For Foucault, and for Butler thereafter, subjection/subjectivation takes on political qualities when the individuals are transformed into the subjects of their own practice (Foucault 1984; Butler 1997). The act of 'taking care of oneself' carries a series of political implications insofar as it both accomplishes and transforms the bio-power. Through a series of 'limit experiences' ('experiences-limite', an expression borrowed from Blanchot regarding experiences that lie out of the ordinary), the subject carries out a self-denial and a self-invention (Foucault 1986). The techniques of the self are operations based on a reasoning about the beautiful, the good, the just and so on whereby the individual is transformed into an ethical subject (Foucault 1988), that is, one who is able to use the power 'for other purposes' (Olivier 1996, 67). Although Foucault mostly does not clarify in which sense this process can be considered properly political, we retain in this idea the transformative potentiality of the act of reflection on and problematisation of the existing.

The subject that emerges out of this process is neither a polished nor a finished product, but a set of new contradictory potentialities. The author who most insists on this 'negative' aspect of subjectivation is Jacques Rancière, for whom politics is first and foremost a 'rupture' ('désidentification') that makes it possible to undo the reproductive classifications of the social order (Rancière 1995). Rancière's subject is realised only in its making, when it is able to remain 'outsider' or 'in-between' (Rancière 1995, 61), and political subjectivation is produced mainly through the rejection of a 'remarkable subject' and the pursuit of an 'indeterminate future without precession or procession' (Fjeld and Tassin 2015). In Rancière, political subjectivation is not the coming to a state (he calls it 'police'), but an opening to new and unknown sets of possibilities: 'a multiple that was not given in the police constitution of the community' (Rancière 1995, 60). In short, it is a 'break' loaded with potentialities and unexpected consequences (see also Žižek 2013).

The contributions of this long tradition in political philosophy emphasise the necessity of considering the individual (and his/her personal transformations) as a fundamental player in the dynamics of political change (Tarragoni 2014). On the one hand, we take inspiration from them to postulate that political action is possibly the result of a reasoning in which the subject is constituted through a process or cognitive and affective reformulation. On the other hand, we consider that, in much of this scholarship (Laclau 2005; Hardt and Negri 2005), political organisation takes second place, and politics appears mostly as the action of a plurality of individuals. Indeed, as also emerges in our analysis, individuals are transformed primarily through their socialisation within a community, commonly consisting of organised or semi-organised groups. For us, focusing on the individual and his/her personal motives does not mean that political subjectivation is an inner monologue. Personal sensibility is converted into a political - that is, collective - project mainly through the relation with forms of shared thought.

Despite their lack of specific reflections on the forms of organisation and their structuring impact on the subject, these authors remain relevant because they make it possible to think of political action as the result of a process that promotes 'work on oneself'. Such work consists of a major ethical shift and, as such, can be analysed through the lenses of a rather different field of studies that has emerged in anthropology in recent years and is dedicated to the theorisation of ethics, morality and freedom. Although an extensive examination of this vast and growing literature is beyond this article's scope, we draw from it some valuable hints. Much of this new scholarship stands out against a Durkheimian, social-deterministic view of society, opposing in particular the equivalence between 
social norms and morality in order to carve out an area of autonomy for the subject and make personal freedom thinkable (Laidlaw 2002; Widlok 2004; Zigon 2008; Yan 2011). Significantly, most of these authors refer to the Foucauldian theorisation on subjectivation as the foundation of the possibility for free choice and liberty. James Laidlaw, for example, cites Foucault's definition of 'techniques of the self' to underline how people's operations on 'their own bodies, their own thoughts, their own souls and their own conduct' presuppose an ethical project aimed at making oneself a specific kind of person (Laidlaw 2002, 322). In such practices, freedom is 'exercised' in forms that are both bound to historically available possibilities and open to new potentialities (Foucault 1984). For Laidlaw 'wherever and in so far as people's conduct is shaped by attempts to make of themselves a certain kind of person, because it is as such a person that, on reflection, they think they ought to live, to that extent their conduct is ethical and free' (Laidlaw 2002,327). In a similar vein, Joel Robbins suggests that we consider all actions that derive from a conscious thinking about oneself and the world as properly 'moral' (Robbins 2007). This point is echoed by Jarret Zigon, who elaborates a sound distinction between 'morality', a practice rooted in non-reflexive and unintentional dispositions, and 'ethics', a specific reflection on oneself and the circumstances. He draws from Heidegger a notion commonly translated into English as 'breakdown' - in German it is 'einer Defizienz des besorgenden Zu-tun-habens mit der Welt' (Heidegger 2006, 61) - to describe the situations in which the usual order of things, the one characterised by non-reflexive behaviours dictated by habit, is shaken by an interrogation that allows one to question values and meanings (Zigon 2007). He calls 'moral breakdown' the circumstances in which 'ethical dilemmas' arise and demand to take a stand. The author emphasises the affinity with the Foucauldian concept of 'problematization', very relevant to our reflection insofar as Foucault himself defined this reflexive moment as an act of freedom. For Zigon, this 'ethical moment' is not solipsism, but a relational move that responds to a social demand. It is also a moment of freedom in which 'people work on themselves, and in so doing, alter their very way of being-in-the-world' (Zigon 2007, 138).

Here again, by insisting on personal self-reflection, these authors give the impression that they prefer to limit the potentialities of ethical reconfiguration to the individual. However, it seems to us that the notions of 'moral breakdown' and 'problematization' open up interesting avenues toward an understanding of what kind of moves are at play in the process of political subjectivation. As we will see in a while, self-reflection and ethical reconfiguration constitute marking moments in the experiences of political engagement. In the case of our interlocutors, a proper 'ethical rupture', in the sense proposed by Zigon, was at play, and was encouraged by the events and by the imaginary possibilities they disclosed.

Through the ethical break that accompanies activism (and its related experiences of estrangement and affiliation), the subject realises a form of life that asserts itself as an example of 'another possible world'. This experience of freedom, realised in a suspended time that would remind many anthropologists of the liminal condition of the ritual described by Van Gennep (1909) and reworked by Turner (1969), lasts until a new order imposes a return to the 'unreflective moral dispositions of everyday life' (Zigon 2007, 135). In the meantime, many things happen until, eventually, 'nothing will ever be the same again'.

\section{A 'Movement' in the proper sense of the term}

The narratives of our Moroccan interlocutors - interviewed with the aim of reconstructing their personal paths to commitment - show recurrently how the new circumstances resulting from the outbursts of popular rage in other countries unleashed a specific interrogation about their own condition, identity and role in the 'hot days' of early $2011{ }^{4}$ Such moments of 'recognition' rested on a feeling of commonality produced by the underlying sense of common identity and opposition to injustice. The exemplum coming from elsewhere represented for many of them a powerful driver for a possible transition from everyday indignation to collective action. In addition, those who had previous experiences of militancy, either personally or within their household, emphasise how the circumstances imposed a new kind of reasoning about conditions and possibilities, one which had the potential to trigger a process of personal transformation.

Redwan, a young man from Rabat with a mild interest in politics and no previous experience of activism, admitted he was deeply impressed when the Tunisian President Ben 'Ali fled his country on 14 January 2011. He calls it 'a turning point, the beginning of a new phase'. He started to join some friends at a café to follow the event on Al Jazeera. He used social networks to get in touch with 'dozens of schoolmates' and receive updates. When he was directed to an event planned for 20 February he did not understand 'who they are' but decided, together with his friends, to show up on that day. He began to join meetings and take an increasingly active role in the organisation of rallies and other events. Redwan's narrative emphasises his personal shift from the sense of helplessness that, according to his words, characterised the past and his investment in new collective hopes. The step from 'subjection' to 'participation' (Almond and Verba 1963) constituted a major subjective movement, sustained by new forms of political imagination, new languages and new opportunities for recognition. Nevertheless, for our 
interlocutors, this is rarely a passage from nothing to all, but is more often a progression across different forms of feeling and thinking the world.

Sukaina gradually moved closer to politics in 2008, after joining a march for Palestine. She had moved from a shantytown located in the outskirts of a city in the North to Rabat to study journalism a few months earlier. Despite the humble conditions of her household, she had always been an excellent student and 'the hope of the family' for a better future, but she had to borrow money from uncles to be able to afford to study away from home. She describes her environment as non-politicised, one in which people commonly reiterated the widespread image of the King as 'a hard worker surrounded by thieves'. At various events on free speech and freedom of the press organised by students, she came in contact with the representatives of the Moroccan Association for Human Rights and started to attend meetings of the Socialist Democratic Vanguard Party (PADS), a left-wing political organisation. She increasingly questioned her upbringing and her values: 'When I arrived in Rabat I was a veiled girl, adopting a typical popular Muslim religion but, as time went on, my way of thinking began to change'. She speaks of 'a revolution against the values and uses that I had acquired', by moving 'from popular Islam to [the condition of] a young layman who believes in difference and tolerance, individual freedoms, and freedom of belief'. Taking advantage of distance, she kept this change hidden from her family for almost two years. On 20 February she gave an interview for a national TV station and went on air. She considers that she belongs to 'the class that had to take to the street', feeling 'compelled to go out to manifest and claim for change and social equity'. For her, the 2011 Movement was an 'opportunity that should not be missed', in part because of the favourable regional and international environment.

'Adil, a young worker from Rabat, concedes he was aware of the existence of 'corruption' (fasād) in society, but was passively accustomed to it: 'That's just the way it is'. He half-heartedly joined the rally on 20 February, but realised the slogans chanted by the growing crowd were in tune with his feelings. He kept on attending rallies without taking up a more active role within the Movement. According to him, this attitude lasted until the day when he was heavily beaten by the police during a sit-in. This event 'disclosed for the first time a different aspect of politics', becoming a marking episode, a turning point in his militancy, which became more intense thereafter. In his testimony, 'Adil highlights his sense of helplessness in the face of 'corruption' and the sudden recognition of the connection between his unarticulated feelings and the keywords of the Movement. For him, this move of identification was a first step on the path leading from private indignation to public commitment. Similarly to other activists, exposure to violence marked for him the passage to a further stage. Violence, especially that which comes from the makhzen, ${ }^{5}$ is often described by activists as the crossing of a new boundary, leading to a deeper awareness of the power relations within society. Repression unleashes its productive potential, contributing to materialising the contradictions inherent in society and make them dramatically concrete.

Hayat grew up in Tetouan, in a working class neighbourhood stigmatised because of its reputation for violence and religious extremism. She dropped out of school early to work with her family 'at the diwāna', a vernacular expression that alludes to the carriers of undeclared goods across the border of Ceuta (Vacchiano 2013). On 20 February she 'went downtown' with some neighbours connected to the Islamist organisation Al-'Adl wa al-Ihsān. She explains it is not necessary to be an activist 'to say no', as everybody was 'tired of hogra'. ${ }^{6}$ Although, as she says, at home they were rather used to living 'hda l-hit' (flanking the wall), she is now convinced that 'people can change the situation' (ash-sha'b yemken ghayyar al-wad'iya). Although her parents are worried for the consequences she might run into, she knows that, in the end, they know she is right.

Living ' $h d a$ l-hit' means to avoid problems, especially with the authorities, to keep a cautious discretion and, most of all, to refrain from protesting. It is an attitude of deference and avoidance that disguises the 'tiredness of life' in order to get by under an authoritarian regime marked by heightened surveillance. It is certainly a daily tactic, in the sense given by De Certeau, and a 'moral disposition of the everyday' in Zigon's sense. Hayat felt an inclination for a particular group, in this case a charismatic Islamist organisation with strong support in working class neighbourhoods, but her initial tendency was to avoid any open affiliation. The step which led her from 'flanking the wall' to 'take to downtown', and later on to a more active role within the Movement, was made possible, once again, by joining other 'neighbours' with whom she experienced the possibility of trespassing the usual social and spatial boundaries. Significantly, the word commonly used by our interlocutors to allude to demonstrations, the same used by Hayat - khrej, 'going out' - conveys this sense of physical and psychological opening. The notion of sha'b (the people) - whose will was affirmed through the famous slogan 'ash-sha'b yurīd ...' (the people want ...) works as a vehicle for a powerful collective identification. The awareness that one is right reinforces the determination and prefigures new possibilities with respect to the roles within the group of origin.

Mohammed grew up in a working-class neighbourhood in a small Moroccan town, where his family moved shortly before his birth. His household's political orientation was mildly conservative and his father was a member of a traditional brotherhood. Mohammed was not particularly interested in politics and deems his early life to have been rather 'normal'. On 20 February he was 17 years old and declared on Facebook his intention to 'stay home playing Playstation'. He considered that he 'had nothing to do with the Movement', that it was against the King and 
aimed at 'destroying the system'. Even today, Mohammed is not completely aware of what made him change of mind. He recalls he had a chat over coffee with two classmates who convinced him to attend a meeting, at which he did not understand most of the topics that were addressed. Yet, he was 'surprised by young people who were goodmannered, educated, and knew what they were talking about'. Inspired by their example, he felt he wanted to 'turn into a person who understands things differently'. He repeatedly emphasises this sense of personal differentiation, with respect to his family, but even more in relation to the conformist way of seeing society and politics. He took a while before confessing to his parents his militancy, but he feels his relationship with them markedly improved thereafter. He assertively maintains that being part of the Movement was 'a superb experience' that changed him, including the direction of his studies (see the next section).

A significant continuity between family and activism emerges in many but, significantly, not all of our interlocutors' life stories. The family has a fundamental role, even if not deterministic, in conveying an ethical orientation toward the world and a broad or specific political vision. While this observation might verge on truism, we can still observe the quality of this transmission and the way in which family orientation is reshaped by new historical conditions.

Kamal hails from a household composed of activists who made their firsts steps into politics in the 1970s, among the ranks of the Socialist Union of Popular Forces (USFP), and then joined the Socialist Democratic Vanguard Party (PADS). During childhood and early adolescence, Kamal found it hard to understand his parents' commitment, which kept them intensely busy and had even led his father to prison on one occasion. His political awareness rose at the summer camps organised by the Moroccan Association of Human Rights (AMDH), which he attended initially as an opportunity to spend time with other kids. As time passed, he felt more and more comfortable taking the floor on issues they were used to debating at home: 'the crisis of education, unemployment, the condition of public health, corruption and cronyism, the separation of powers, the monarchy'. Logically enough, he feels his involvement within the Movement from the outset was the natural continuation of his political socialisation. And yet, he considers that, despite pushing him to attend summer camps, his parents' imprinting on his worldview has been less influential than that of his peers - proof of which can be found in the fact that his brothers and sisters are not politically active. In addition, he maintains that the Movement is 'a space of participation, much more open and free' than the formal ways pursued by his parents, mostly through party politics.

Interestingly, Younes, who is from a family largely affiliated to the Islamist group Al-'Adl wa al-Ihsān, also feels the need to underline his personal choice in relation to politics, stating repeatedly that he was left free to form his own ideas within the household. Yet, he acknowledges that his whole family took part to the rallies organised by the Movement in Spring 2011, and that they shared the same views concerning the situation of the country and the need for an Islamist turn in Morocco. He states that he has been 'always interested in politics', ever since he watched the news with his father and listened to the grown-ups discussing social and political issues. Very early he says at 13 - he read some of Hassan Al-Banna's and the Muslim Brotherhood's pamphlets he found at home and approached a Moroccan Brotherhood- inspired group, Al-Tawhīd wa al-Islāh. Right after 20 February, after the groups's declaration of allegiance to 'the system', he abandoned Al-Tawhīd wa al-Islāh in order to formally join 'the Jamā'a', the name used by militants for Al-'Adl wa al-Ihsān. As a committed representative of the organisation, Younes, who was only 14 at the time, worked to establish a branch of the 20 February Movement in high schools, the 'Movement of the students' (Haraka al-Talmadiyya). After initial reluctance, Younes's father encouraged him to take part in demonstrations and push the Jamā'a's orientation at the Movement's meetings, a mandate that caused recurrent conflict with the members of other political groups. Allegedly, this had the effect of bolstering Younes's political conviction. Six years after the events, Younes is more active than ever, being personally committed to the radical project expressed by the Jamā'a: its 'political and educational' goals, its 'organizational capacity', its long-term strategic thought aimed at preparing the ground for the establishment of a new khilāfa ('caliphate'). In particular, he stresses the 'ethical behaviour' of its members, who 'were always in the first row' and whose commitment 'was not enfeebled by threats and detention'. He personally suffered police violence and detention for his active role in the demonstrations supporting the Hirak, the movement that originated in the Rif after the death of Muhsin Fikri (Lefèvre 2017; Wolf 2018), and is now convinced that the time is not right for revolution, but 'a patient work of sowing' must be undertaken with a view to securing a better future. He confides that 'before' he was too direct, impulsive and reckless, exposing himself to risks and even considering death as a possibility, whereas now he agrees that society must be led toward change through the patient work of 'education'. With this goal in mind, he matriculated in Political Science and plans to apply for a grant offered by an Islamist organisation to complete his studies in Turkey. He aspires to become a university professor and to join the professors' union in order to bring about his political view within the category. He qualifies this mission as a form of jihād, which, he observes, 'cannot be only directed frontally against the system'.

Well beyond what he is willing to admit, Younes - not unlike Kamal - is enacting a family mandate, assimilated from his childhood and ratified in the early days of the revolt when his father used to call him 'his crown prince'. Nonetheless, Younes seems to have exceeded his parents in terms of ideology and militancy, turning his political posture into a life choice, a movement in the proper sense of the term and one that is bound to last. 
Similarly to Redwan, Sukaina, 'Adil, Hayat, Mohammed and Kamal, for Younes the process of political subjectivation is the result of involvement in new 'spaces of experience' (Pleyers and Capitaine 2016), a series of situations of relational learning in which new roles and forms of life are lived out and gradually appropriated. Even when this occurs in continuity with primary socialisation, it is also a process of personal differentiation. Ironically, unawareness of causes and processes is a sign of effectiveness and durability, inasmuch as subjectivation rests also on forms of embodiment that, as such, are not immediately reached by reasoning. Through the enactment and rehearsal of these new forms of being-in-relation, the subjective shift is consolidated and paves the way to new choices.

\section{A structuring utopia and an unfinished project}

In the introduction to his famous essay on hope and utopia, Ernst Bloch claims that political imagination cannot be thought of without considering hope as an orienting sense. For Bloch, 'hope is not taken only as emotion [...] but more essentially as a directing act of cognitive kind' (Bloch 1995, 12). Due to its capacity to prefigure a desirable future, a 'Not-Yet', hope lays the foundations of utopia, 'in the new tenable sense of the forward dream, of anticipation in general' (Bloch 1995, 12). In a later section of the book, he defines a 'concrete utopia' as the attitude to connect 'dreams and life' within a 'Real-Possible' (Bloch 1995, 145-146). Rather logically, Bloch observes that 'all freedom movements are guided by utopian aspirations' (Bloch 1995, 7). In a later essay, written again by straddling philosophy and literature, Bloch defines utopia as the way 'to find it, to find the right thing, for which it is worthy to live, to be organised, and to have time' (Bloch 2000,3). A concrete utopia is a perspective of change that is perceived at hand and, as such, is apt to organise hope around a possible future and give a direction to life, a way of pursuing 'a sense' for what comes and for what one wants to become. Utopia outlives failure and keeps alive hope by postponing its coming. Under adverse circumstances, deferment provides a powerful way of enduring the present by anticipating alternative possibilities and making everyday life liveable. Most likely, every human being needs a kind of utopian project, framed either by religion, politics or economy (and frequently by all of these at once). Its concreteness rests on a projection that is rendered plausible by putting oneself in it, that is, by committing personally to the future.

The 'forward dream' is often shaped as a compensatory image of the present, an overturning of the traits of one's own perceived condition, a 'revolution' in the literal sense of the term. Now, our interlocutors in Morocco recurrently qualify their social experience through notions like tkarfis (suffering), fasād (corruption,

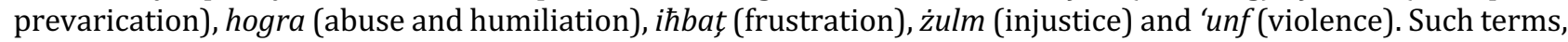
redundantly employed to describe the sense of inequity in everyday life, remind us of the words of those who aspire to emigrate (Elliot 2016; Menin 2016; Vacchiano 2018a, 2018b). They describe the perceived imbalance between aspirations and possibilities and the lack of conditions (żuruf) that qualify as 'a decent life' ('aysh karim) in today's world. Significantly, the most renowned slogans chanted across the Arab streets in 2011, and readapted by the Movement in Morocco, echoed almost symmetrically these feelings.

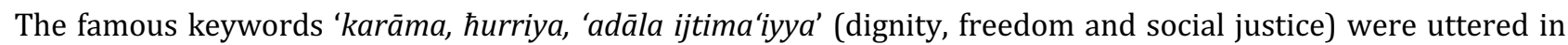
slogans and chants that were effective in breaking with individual helplessness and encompassing different sensitivities. For our interlocutors, 'dignity' is a specific reference to personal value, respect and well-being (as in the expression 'aysh karīm, 'decent life'); 'freedom' is a claim for self-determination against state control over political opinions and collective morality; 'social justice' refers to the inversion of social imbalances and summarises a fairer society at large. Indeed, these notions are sufficiently ambiguous to create a semantic space of recognition in which one's experience can be projected: everybody is free to find a personal way of positioning themselves, and eventually - as in 'Adil's case - may be surprised by recognising their feelings are shared by other people. The efficacy of such claims seems to exceed circumstances and bear long-lasting effects. For many of those who decided 'to say no' (an expression used by Bloch but also commonly employed in many Arab countries: see also Schielke 2015), they turned into a kind of 'structuring utopia', one which shaped personal lifegoals and showed a way forward.

Redwan is now an active member of a recently established Moroccan NGO for research and consultancy in the area of social participation. His movement from mild curiosity to involvement has allowed him to increase his awareness of social imbalances and to gain self-confidence and a sense of initiative. He believes that the 20 February Movement had broad ambitions in terms of social and political change and that its tangible achievements have been limited. Yet, he considers that the principle that people can rise and claim their rights was affirmed once and for all. He keeps on hoping for a better society and feels satisfied with working actively to pursue it. Today, Sukaina works for an international NGO and militates in the same left-wing party to which she drew close before the revolt. For her, the militancy within the Movement has been 'one of the best experiences in life', and with the Movement she feels she has lived out freedom and deep friendship. Whenever she listens to the slogans chanted in demonstrations, she recognises the words that the young people of the Movement imagined and wrote. She 
married a comrade from the Movement and, although her parents are still deferential toward 'the system', they have been gradually drawn closer to her political views. 'Adil has undertaken studies in Law and aims to become a lawyer working with political detainees. He is currently an activist for the Moroccan Association for Human Rights and sees his engagement as the unequivocal continuation of his 2011 militancy. Admittedly, he chose to study Law because the debates within the Movement demanded 'a deep knowledge of law or social sciences', and because the majority of the young people who influenced his views were students in Law. Hayat married an active member of Al-Adl wa al-Ihsān, although the intensity of her militancy is still fluctuating. Mohammed is also enrolled in a MA programme in Law and works as a volunteer in the same NGO as Redwan. He convincingly maintains that '20 Febrair madrasa' ('20 February is a school'), an experience that 'generated a big metamorphosis' and that motivated him 'to study to understand things'. For his part, Kamal is now employed as a computer technician in a state-owned company. During his militancy, he came to understand the power of new media, and turned information technology into his job. Although he estimates that things have not significantly changed, he is convinced that the Movement has opened new avenues by giving legitimacy to the act of protesting. For this reason, since 'many people still have nothing to lose', a new uprising is likely to occur in the future. If and when it does, he plans to make himself useful by transmitting his technical skills to 'a new generation of activists'. As for Younes, his plan is laid out clearly: he sees his ambition to become a professor in political science as a personal jihad (literally: 'an effort') that will enable him to pursue his 'educational' programme toward a society informed by Islamic principles.

Other 20 February activists also undertook studies in social sciences and philosophy, and today work in NGOs or human rights organisations or have joined political parties. Some met their current partners through their activism, and almost all redefined their personal roles and duties with regard to the family. Thus, an intimate revolution accompanied the public engagement of 2011 and beyond. Political subjectivation has both public and intimate stakes, although the political significance of each is not always the same.

The transition from 'uprising' to 'activism' is a passage from the quick eruption of subversive passion and collective effervescence to the strategic essentialism of a patient, often interstitial, daily struggle for spaces of movement within the meshes of hegemony. Taking inspiration from Turner again, it is a move between 'communitas' and 'structure', a 'social drama' in which breach and crisis necessarily give way to redress and reintegration (Turner 1969, 1988; Thomassen 2012). Revolution is temporary by definition. In the experience of our interlocutors, the return to the ordinariness of the 'cold time' is well represented by the shift from 'justice' to 'law'. Stepping from ' $a d l$ to $\hbar a q q$ is doubtless a normalisation of the struggle and its insertion into a domain of action supervised by the ruling power. Yet, it is also a way to preserve the value of the 'concrete utopia' under other circumstances, keeping hope alive, carving out conditional spaces of possibility in the present and postponing its full accomplishment to the future. Protracted activism in a regime of ordinariness needs utopia in order to hold a direction. Add to this, in a largely authoritarian state, evoking human rights (al-huqūq al-insān) and the rule of law is to resort to a language that allows one to convey again, to different audiences, the call for dignity, freedom and social justice.

\section{Conclusions: to be disidentified with power}

In an insightful pamphlet written 'on the spot' in the Spring of 2011 (Benslama 2011), the Tunisian psychoanalyst Fethi Benslama questioned the 'flagrant' (éclatants) events of his country in order to understand how it was that something deemed simply inconceivable a few months ago - nothing less than a revolution - had 'suddenly' become possible. His reflection hinges on the idea that the self-immolation of Tāriq Muhammad Al-Bou 'Azizi provoked, in the minds of his fellow citizens, a spark without previous references, a process of radical rupture above all with themselves: 'a new perception, [...] a sudden breaking of meaning, a [...] dazzling desire that sets in motion passion, language, representation' (Benslama 2011, 16). For Benslama, this 'ejection', this displacement that takes one 'out of oneself', enabled a psychic separation from the structures of subjection and generated a new collective identification, on one side with the martyr and on the other side with 'the people'. For Benslama, this subjectivation, occurring in circumstances where 'chance meets necessity' (Benslama 2011, 33), is achieved through a powerful emotional movement that breaks the consolidated structures of the imaginary and opens up unexpected, potentially revolutionary, configurations.

It seems to us that this movement of 'swerve' (Rancière calls it 'écart') is the condition of possibility for an ethical break that consents to question the legitimacy of the ruling power and the resulting 'voluntary servitude'. In order to be properly political, however, this change of direction needs to be ratified and shared in a collective environment, becoming a plausible project, a 'concrete utopia', also for others. Only a form of collective organisation - a party, a group or, under very specific conditions, a 'multitude' - can authorise and make effective the passage from daily malaise, when people resist injustice, to hope in a revolution.

In analysing this shift, we found a very specific combination of personal dispositions, historical circumstances, forms of collective identification and organised thought. The 20 February Movement in Morocco represented the 
coalescence of these factors and became an environment in which individual sensitivity could be turned into an organised project. It was, at the same time, both a trigger for personal change and a result of it. Our interlocutors recount this moment in their lives as a fundamental passage, an existential turning point that ended up influencing their subsequent choices. In this sense, the comparison with the ritual process is striking. This shows us that, even if it is carried out in very specific circumstances, the act of 'problematization' has consequences that last well beyond the moment of its emergence: 'breakdown', in this case, did not seem to give way to the return to an unreflected everyday condition. Like any significant experience, political subjectivation prompt a metamorphosis in the way in which the individuals position themselves with respect to the world. Yet, perhaps unlike any other experience, it produces also a discourse on the world and a reflection on the posture one assumes personally towards the power which is fostered by a shared, structuring utopia. Therefore, even though the revolt has not kept all its promises, at least some of its changes have come to stay. For many of its protagonists, the Spring has not exhausted its potentialities and 'the long 2011 ' is still running.

\section{Notes}

1. Fundação para a Ciência e a Tecnologia (FCT), IF/01002/2014/CP1239/CT0003.

2. Al-Wasīe min ajli ad-Dimukratiyya wa Huqūq al-Insān (The Mediator for Democracy and Human Rights), Haraka 20 Fibräir. Muĥawala fi At-Tawthïqi (The 20 February Movement. An Attempt of Documentation), Rabat, 2015.

3. For an exposition of convergences and divergences in considering subjectivity in anthropology and psychoanalysis, see Moore (2007).

4. On the cyclical swing of 'cold' and 'hot' periods in Morocco see Bennani-Chraïbi (1994).

5. Literally: 'storehouse'. It is the term that designates the authority and its agents in Morocco, alluding to the buildings where in-kind tributes were stored in the past.

6. The vernacular term, common in the whole Maghreb and recently extended to other Arab countries, used to refer to the humiliation, abuse and prevarication committed by the authorities.

\section{Acknowledgements}

We wish to thank all our interlocutors in Morocco, who gave a fundamental contribution to this study. This article is dedicated to Mourad Lamkhantar.

\section{Funding}

This research is supported by national funds provided by the Fundação para a Ciência e a Tecnologia (FCT) of the Portuguese Ministry of Science and Technology, in the framework of the exploratory project IF/01002/2014/CP1239/CT0003.

\section{References}

Abdelrahman, Maha. 2011. "The Transnational and the Local: Egyptian Activists and Transnational Protest Networks." British Journal of Middle Eastern Studies 38 (3): 407-424.

Akçali, Emel. 2016. "Introduction: Neoliberal Governmentality and the Future of the State in the Middle East and North Africa." In Neoliberal Governmentality and the Future of the State in the Middle East and North Africa, 1-14. London: Palgrave Macmillan.

Almodóvar, Marc. 2014. Egipto tras la barricada : revolución y contrarrevolución más allá de Tahrir. Barcelona: Virus Editorial. Almond, Gabriel, and Sidney Verba. 1963. The Civic Culture: Political Attitudes and Democracy in Five Nations. Newbury Park, CA: SAGE Publications.

Arendt, Hannah. 1958. The Human Condition. Chicago: University of Chicago Press.

Bayart, Jean-François. 2013. "Retour sur les Primtemps Arabes.” Sociétés Politiques Comparées 35. Accessed 8 March 2019. http://fasopo.org/sites/default/files/article_n35.pdf.

Bayat, Asef. 2010. Life as Politics: How Ordinary People Change the Middle East. Amsterdam: Amsterdam University Press.

Belghazi, Taieb, and Abdelhay Moudden. 2015. "Ihbat: Disillusionment and the Arab Spring in Morocco." The Journal of North African Studies 21 (1): 37-49.

Bennani-Chraïbi, Mounia. 1994. Soumis et Rebelles: Les Jeunes au Maroc. Paris: CNRS Editions.

Benslama, Fethi. 2011. Soudain la Révolution! De la Tunisie au Monde Arabe: La Signification d'un Soulèvement. Paris: Denoël. 
Bloch, Ernst. 1995. The Principle of Hope. Vol. 1. Cambridge, MA: Mit Press.

Bloch, Ernst. 2000. The Spirit of Utopia. Stanford, CA: Stanford University Press.

Bogaert, Koenraad. 2013. "Contextualizing the Arab Revolts: The Politics behind Three Decades of Neoliberalism in the Arab World." Middle East Critique 22 (3): 213-234.

Bogaert, Koenraad. 2018. Globalized Authoritarianism: Megaprojects, Slums, and Class Relations in Urban Morocco. Minneapolis: University of Minnesota Press.

Bono, Irene, Béatrice Hibou, Hamza Meddeb, and Mohamed Tozy. 2015. L'État d'Injustice au Maghreb. Paris: Karthala.

Butler, Judith. 1997. Excitable Speech: A Politics of the Performative. New York: Routledge.

Campante, Filipe R., and Davin Chor. 2012. "Why was the Arab World Poised for Revolution? Schooling, Economic Opportunities, and the Arab Spring.” The Journal of Economic Perspectives 26 (2): 167-187.

De Certeau, Michel. 1990. L'invention du Quotidien, Tome 1: Arts de Faire. Nouv. éd. Paris: Gallimard.

Desrues, Thierry. 2012. "Moroccan Youth and the Forming of a New Generation: Social Change, Collective Action and Political Activism." Mediterranean Politics 17 (1): 23-40.

Dhillon, Navtej, Paul Dyer, and Tarik Yousef. 2009. “Generation in Waiting: An Overview of School to Work and Family Formations Transition." In Generation in Waiting: The Unfulfilled Promise of Young People in the Middle East, edited by Navtej Dhillon and Tarik Yousef, 11-38. Washington, DC: Brookings Institution Press.

Elliot, Alice. 2016. "The Makeup of Destiny: Predestination and the Labor of Hope in a Moroccan Emigrant Town." American Ethnologist 43 (3): 488-499.

Festinger, Leon. 1957. A Theory of Cognitive Dissonance. Stanford: Stanford University Press.

Fjeld, Anders, and Étienne Tassin. 2015. "Subjectivation et Désidentification Politiques. Dialogue à partir d'Arendt et de Rancière." Ciencia Política 10: 193-223.

Foucault, Michel. 1984. Histoire de la Sexualité 3: Le Souci de Soi. Paris: Gallimard.

Foucault, Michel. 1986. La Pensée du Dehors. Fata Morgana: Montpellier.

Foucault, Michel. 1988. “"Technologies of the Self”.” In Technologies of the Self: A Seminar with Michel Foucault, edited by Luther H. Martin, Huck Gutman, and Patrick H. Hutton, 16-49. Amherst: University of Massachusetts Press.

Gertel, Jörg. 2017. “Arab Youth: A Contained Youth?” Middle East - Topics and Arguments 9: 25-33.

Hanieh, Adam. 2013. Lineages of Revolt: Issues of Contemporary Capitalism in the Middle East. Chicago: Haymarket Books.

Hardt, Michael, and Antonio Negri. 2005. Multitude: War and Democracy in the Age of Empire. New York: Penguin Group.

Heidegger, Martin. 2006. Sein und Zeit. Tübingen: De Gruyter.

Hibou, Béatrice. 2006. La Force de L'Obéissance: Économie Politique de la Répression en Tunisie. Paris: La Découverte.

Hibou, Béatrice. 2011. “Tunisie. Économie Politique et Morale d'un Mouvement Social.” Politique africaine 121 (1): 5-22.

Honwana, Alcinda. 2013. Youth and Revolution in Tunisia. London: Zed Books Ltd.

King, Stephen J. 2007. "Sustaining Authoritarianism in the Middle East and North Africa." Political Science Quarterly 122 (3): 433-459.

Laclau, Ernesto. 2005. On Populist Reason. New York: Verso.

Laidlaw, James. 2002. "For an Anthropology of Ethics and Freedom." The Journal of the Royal Anthropological Institute 8 (2): 311-332.

Lefèvre, Raphaël. 2017. “'No to Hoghra!': Morocco's Protest Movement and its Prospects.” The Journal of North African Studies 22 (1): $1-5$.

Menin, Laura. 2016. “'Men do not get Scared! (rjjala mā tāy-khāfūsh)': Luck, Destiny and the Gendered Vocabularies of Clandestine Migration in Central Morocco." Archivio Antropologico Mediterraneo 18 (1): 25-36.

Moore, Henrietta L. 2007. The Subject of Anthropology: Gender, Symbolism and Psychoanalysis. Cambridge: Polity.

Muldering, M. Chloe. 2013. “An Uncertain Future: Youth Frustration and the Arab Spring.” The Pardee Papers 16: 1-38.

Murphy, Emma C. 2012. "Problematizing Arab Youth: Generational Narratives of Systemic Failure.” Mediterranean Politics 17 (1): 5-22.

Olivier, Lawrence. 1996. "Michel Foucault, Éthique et Politique." Politique et Sociétés 29: 41-69.

Osman, Tarek. 2012. “Young Egyptians: Their Society and Future.” Social Research 79 (2): 299-322. 
Petrovic, Igor, Jacquelien van Stekelenburg, and Bert Klandermans. 2014. "“Political Socialization and Social Movements. Escaping the Political Past?"." In The Palgrave Handbook of Global Political Psychology, edited by H. Dekker, C. Kinnvall, and T. Capelos, 403-422. Basingstoke, NY: Palgrave Macmillan.

Pleyers, Geoffrey, and Brieg Capitaine. 2016. Mouvements Sociaux: Quand le Sujet Devient Acteur. Paris: Maison des Sciences de l'Homme.

Rancière, Jacques. 1995. La Mésentente: Politique et Philosophie. Paris: Editions Galilée.

Robbins, Joel. 2007. "Between Reproduction and Freedom: Morality, Value, and Radical Cultural Change.” Ethnos 72 (3): 293314.

Schielke, Samuli. 2015. Egypt in the Future Tense: Hope, Frustration, and Ambivalence Before and After 2011. Bloomington: Indiana University Press.

Scott, James C. 1985. Weapons of the Weak: Everyday Forms of Peasant Resistance. New Haven: Yale University Press.

Scott, James C. 1990. Domination and the Arts of Resistance: Hidden Transcripts. New Haven: Yale University Press.

Shafer, Isabel. 2015. Youth, Revolt, Recognition. The Young Generation During and After the 'Arab Spring'. Berlin: Mediterranean Institute.

Tarragoni, Federico. 2014. “La Prise de Parole Comme Processus de Subjectivation Politique.” Tumultes 43: 175-190.

Tarragoni, Federico. 2016. “Du Rapport de la Subjectivation Politique au Monde Social.” Raisons Politiques 62: 115-130.

Tassin, Etienne. 2012. “De la Subjetivación Política: Althusser/Rancière/Foucault/Arendt/Deleuze.” Revista de Estudios Sociales 43: 36-49.

Tazzioli, Martina. 2017. Tunisia as a Revolutionized Space of Migration. London: Palgrave.

Thomassen, Bjørn. 2012. "Notes towards an Anthropology of Political Revolutions." Comparative Studies in Society and History 54 (3): 679-706.

Turner, Victor W. 1969. The Ritual Process: Structure and Anti-Structure. Chicago: Aldine Pub. Co.

Turner, Victor. 1988. The Anthropology of Performance. New York: PAJ Publications.

Vacchiano, Francesco. 2013. "Fencing in the South. The Gibraltar Area as a Paradigm of the New Border Regime in the Mediterranean." Journal of Mediterranean Studies 22 (2): 337-364.

Vacchiano, Francesco. 2014. "Beyond Borders and Limits: Moroccan Migrating Adolescents between Desire, Vulnerability and Risk." Saúde e Sociedade 23 (1): 17-29.

Vacchiano, Francesco. 2018a. “Desiring Mobility. Children's Migration, Parents' Distress and Constraints on the Future in North Africa." In Research Handbook on Child Migration, edited by Jacqueline Bhabha, Daniel Senovilla Hernández, and Jyothi Kanics, 82-97. London: Edward Elgar Publishing.

Vacchiano, Francesco. 2018b. “Du kariān au hreg et retour. Spatialité des marges juvéniles et désir d'émigration au Maroc.” In Citadinités Subalternes en Afrique, edited by Thomas Fouquet, and Odile Goerg, 157-175. Paris: Karthala.

Van Gennep, Arnold. 1909. Les Rites de Passage. Paris: Editions A\&J Picard.

Widlok, Thomas. 2004. "Sharing by Default? Outline of an Anthropology of Virtue." Anthropological Theory 4 (1): 53-70.

Wolf, Anne. 2018. "Morocco's Hirak Movement and Legacies of Contention in the Rif." The Journal of North African Studies 24 (1): 1-6.

Yan, Yunxiang. 2011. "How Far Away Can We Move from Durkheim? Reflections on the New Anthropology of Morality." Anthropology of This Century 2 (October). Accessed 8 March 2019. http://aotcpress.com/articles/move-durkheim-reflectionsanthropology- morality/.

Zigon, Jarrett. 2007. "Moral Breakdown and the Ethical Demand A Theoretical Framework for an Anthropology of Moralities”. Anthropological Theory 7 (2): 131- 150. doi:10.1177/1463499607077295.

Zigon, Jarrett. 2008. Morality: An Anthropological Perspective. Oxford: Berg.

Žižek, Slavoj. 2013. Less Than Nothing: Hegel and the Shadow of Dialectical Materialism. London: Verso Books. 